[Reprinted from the American Journal of Botany, 4: 604-623, December, I9I 7.]

\title{
REVISION OF THE HAWAIIAN SPECIES OF THE GENUS CYRTANDRA, SECTION CYLINDROCALYCES HILLEBR.
}

\section{JOSEPH F. ROCK \\ INTRODUCTION}

The genus Cyrtandra is represented in the Hawaiian Islands by a considerable number of species. To the 32 enumerated by $C$. B. Clarke in his monograph, several new ones have already been added and there still remain to be described at least seven species and as many varieties.

It is to be regretted that much confusion exists in the taxonomy of the Hawaiian species. This was mainly caused through the works of C. B. Clarke and Hillebrand, both of whom described the same species of Cyrtandrae contemporaneously, the one not being aware of the other's labors.

C. B. Clarke's monograph, as far as Hawaiian species are concerned, is based mainly on the collections of Gaudichaud, Barclay, Wawra, Mann and Brigham, Nuttall, Asa Gray, and partly on specimens forwarded by Hillebrand with manuscript names.

Hillebrand had evidently not forwarded a complete set of his duplicates to Berlin and Kew, for practically none of the Hillebrand material in the Berlin Herbarium bears C. B. Clarke's determinations, whereas they are present on all specimens collected by Gaudichaud, Wawra and other earlier botanists, whose material is deposited in the various herbaria of Europe and America.

In the Berlin Herbarium, where the writer was privileged to work on the Hawaiian collection, he found C. B. Clarke and Hillebrand's species still in separate covers, notwithstanding the fact that Hillebrand's species, or at least some of them, are identical with Clarke's species.

For example, Hillebrand's Cyrtandra latebrosa (Fl. Haw. Isl. 337. I888) is Cyrtandra longifolia Hillebr. var. degenerans C. B. Clarke, and published as such in the latter's monograph on the tribe Cyrtandreae. Hillebrand distributed material of this species under Cyrtandra longifolia, which name was adopted by Clarke, giving Hillebrand credit 
for it as author, while Hillebrand himself published the same species under the name Cyrtandra latebrosa without mentioning his former manuscript name. On still another sheet we find for the same species still another name-Cyrtandra paradoxa. Again, a specimen in the herbarium at Vienna, No. I99I, marked Cyrtandra paludosa Gaud. var. a longifolia Wawra, which is a synonym of Cyrtandra longifolia Hillebr. (in Clarke Monogr. 276. I883), was selected by C. B. Clarke as the type for Hillebrand's manuscript name $C$. longifolia.

It is the writer's desire to clear up all this confusion. He was in a position to examine the material which formed the basis for C. $\mathrm{B}$. Clarke's monograph, and he also compared the same with Hillebrand's collection.

The larger portion of Hillebrand's material was not known to C. B. Clarke, as it came into the possession of the Berlin Herbarium after Hillebrand's death.

This paper is the first of a series on the genus Cyrtandra and contains a critical revision of the section Cylindrocalyces Hillebr.

SECTION ONE: CYLINDROCALYCES Hillebr. Fl. Haw. Isl. 326. 1888

Calyx campanulate, cylindrical or fusiform, five-cleft into unequal lobes, splitting laterally at last; corolla usually large, curved, bilabiate; flowers single or few, subumbellate to cymose; leaves mostly glabrous, or, when tomentose, usually so along the midrib and nerves underneath, with blackish or dark brown to reddish hair, of ten thickly matted (C. longifolia, var. degenerans).

This section possesses now seven species, ten varieties, and four forms, of which one species, two varieties, and four forms, are here described for the first time.

The species are closely related, for example: $C$. paludosa and $C$. longifolia; $C$. cyaneoides and $C$. waianuensis; $C$. grandiflora and C. filipes; $C$. oenobarba var. petiolaris appears to come more or less close to $C$. longifolia var. calpidicarpa, in the long cylindrical fruit.

Cyrtandra paludosa Gaud. Bot. Voy. Uranie 447. I830. Var. $\alpha$ TYPICA C. B. Clarke Monogr. Cyrt. 5: 275. I883-I887

A low shrub, the young parts silky to rusty-tomentose; branches glabrous, somewhat fleshy; leaves opposite, elliptical-oblong, thick, chartaceous, acuminate at both ends, with crenate to serrate margins, almost glabrous when mature, dark green above, pale underneath, the veins straight and prominent, $10-22 \mathrm{~cm}$. long, $4^{-6} \mathrm{~cm}$. wide, on 
petioles of 2-6 cm.; peduncle short, $5 \mathrm{~mm}$. long; cyme few- $(3-7)$ flowered; bracts 6-8 mm., long-acuminate, covered with reddish brown hair; pedicels 6-10 $\mathrm{mm}$. long; calyx cylindrical to campanulate, thin, IO-I $5 \mathrm{~mm}$., unevenly 5 -fid to the middle or less into lanceolate, acuminate lobes, splitting laterally, caducous when with fruit, partly hirtellous or glabrous; corolla I 5-20 mm., suberect, exserted, glabrous, white; fruit $12-20 \mathrm{~mm}$. long, 5-8 mm. broad, glabrous.

OAHU: ex. Coll. Gaudichaud no. I54, Iles Sandwich, visit I84I, in herb. Berlin, and part of type in College of Hawaii herbarium; Ins. Sandwic. Oahu, Meyen 5/3I, labeled C. Garnottiana det. C. B. Cl. C. paludosa, and Meyen C. triflora Gaud. det. C. B. Cl. C. paludosa Woahoo, Ins. Sandw. Macrae, Maio I825, in herb. Soc. Hort. Lond. and in herb. Berlin; Lindley visit 1832 in herb. Berlin; Hawaiische Inseln, Wawra no. I665, Oahu, fruiting and flowering (three sheets) in herb. Vienna and herb. College of Hawaii, and no. 2375 leg. Hbd. comm. Dr. Wawra, in herb. Vienna; Niu Valley, Oahu, leg. Lydgate, Willi, I87o, herb. Hillebr. Berlin; Kalihi, Oahu, Jan. I87o, leg. Hbd. fruiting specimen in herb. Berlin; Palolo Valley, main ridge, flowering, Nov. 7, I908, Rock no. 96 in herb. College of Hawaii; Punaluu Mts., Koolau, flowering Nov. I4-2I, I908, Rock no. 29I in herb. College of Hawaii; Waikane Mts., flowering, Jan. 23, I909, Rock no. 125I in herb. College of Hawaii.

The Oahu specimens are the typical C. paludosa $\alpha$ typica C. B. Clarke. The species occurs on Hawaii also, but is much smaller in every way.

HawaII: Kilauea, leg. Hillebr. April 1868, flowering, in herb. Berlin; Hilo, leg. Lydgate in herb. Berlin (with small narrow leaves); Kalanilehua, Kilauea, flowering, May I912, Rock no. 10343 in herb. College of Hawaii; Alakahi Kawainui along ditch trail, flowering and fruiting, July I3, I909, Rock no. 4473 (two sheets) in herb. College of Hawaii; Alakahi ditch in swampy forest, flowering, June r9Io, Rock no. $85 \mathrm{I} 3$ in herb. College of Hawaii.

The specimens from Alakahi and Kawainui gorges, near the summit of the Kohala mountains, at an elevation of 4,200-4,500 feet, differ considerably from the typical specimens occurring on Oahu; on Hawaii where they grow in dense swampy forests in thick Sphagnum moss they are only 2-3 feet in height, the leaves are smaller, ovateelliptical, much more coarsely serrate, of thicker texture, and on shorter petioles; the peduncles are shorter than in the Oahu specimen, or are almost wanting; the calyx is glabrous and not thin. It would 
perhaps be better to class these plants as a distinct variety, but owing to the polymorphism of most of the Hawaiian plants it may cause confusion if raised to varietal rank.

The plants from Kilauea (no. I0343) have still smaller leaves (elliptical-lanceolate) and the branches are very slender, otherwise the same.

Cyrtandra paludosa Gaud. var. Brevicalyx Hillebr. Fl. Haw. Isl. 336. I 888

Leaves as in the species $\alpha$ typica C. B. Cl. though broader, on stout petioles of $2.5-5 \mathrm{~cm}$.; peduncle very short or almost wanting, of ten only one-flowered, the filiform pedicels $18-36 \mathrm{~mm}$; calyx only one third the length of the corolla, $6-8 \mathrm{~mm}$., cyatiform with broad acuminate lobes or teeth; berry slender, fusiform, $20-24 \mathrm{~mm}$. long.

OAHu: Kaala range, Hillebrand, July 1870 , in Herb. Berlin (doubtfully referred here a specimen from the Waikane Mts. flowering and fruiting Jan. 23, 1909, Rock no. II35 in herb. College of Hawaii).

This variety differs from the species in the slender, long pedicels, short peduncle and small calyx, perhaps only a form of the typical species.

The writer's specimen from the Waikane Mts. have long, very slender, pedicels (a little over $18 \mathrm{~mm}$.) but a distinct peduncle, the calycine lobes being very short as is the calyx tube.

Cyrtandra paludosa Gaud. var. alnifolia Hillebr. Fl. Haw. Isl. 336. 1888

Young shoots and inflorescence hirsute with dark ferruginous hairs; leaves broadly ovate, Io-I $2.5 \mathrm{~cm}$. long, $6-7.5 \mathrm{~cm}$. wide, somewhat obtuse, rounded at the base, the strong ribs and veins pubescent; peduncle and pedicels $12-14 \mathrm{~mm}$. each; calyx and corolla faintly pubescent.

OAHU: Hillebrand in herb. Berlin.

This variety can be retained; in its general appearance it is a typical $C$. paludosa but differs from $\alpha$ typica only in the longer peduncles and pedicels, and in the young leaves, which are covered with a fulvous tomentum.

Cyrtandra Paludosa Gaud. var. microcarpa Wawra

Flora 55: 560. I 872 (not Hillebr.)

Plant low, I m., rarely more, scarcely branching; leaves as in $C$. paludosa $\alpha$ typica though somewhat larger, light green above, fawn 
colored underneath, the midrib and veins prominent, covered with a silky, brown, pubescence; petioles about $4 \mathrm{~cm}$.; inflorescence densely clustered in the leaf-axiles covered with a brown, coarse pubescence; peduncles short, $\mathrm{o}^{-4} \mathrm{~mm}$., many-flowered; pedicels 5-20 mm., umbellate; calyx $8 \mathrm{~mm}$. long, subglabrate, caducous; corolla I2-I4 $\mathrm{mm}$. long, tube narrow, curved, glabrous; fruit $\mathrm{I} \mathrm{cm}$. long, 5-6 mm. broad, numerous, subconglomerate.

KAUAI: In the forests above Waimea, Wawra no. 2056 in herb. Vienna, and herb. College of Hawaii; Kealia and Waimea leg. Knudsen, in herb. Berlin; at the head of Olokele canyon along rockwalls, flowering Oct. I909, Rock no. 54I4 in herb. College of Hawaii.

Hillebrand's var. $\delta$ microcarpa is identical with Wawra's var. microcarpa and is therefore preoccupied by Wawra; there are three sheets in the Vienna herbarium ex Coll. Wawra.

Hillebrand says: "including probably Wawra's var. confertiflora and herbacea." His variety confertiflora does not belong to C. paludosa Gaud.; it was described by C. B. Clarke in his monograph as C. confertiflora (Wawra) Clarke and that justly, for the plant has no resemblance to $C$. paludosa.

Wawra's var. herbacea does not belong to $C$. paludosa Gaud. but to $C$. oenobarba and Heller's combination ( $C$. oenobarba herbacea Heller) is therefore correct.

Cyrtandra paludosa Gaud. var. subherbacea Wawra, Flora 55: 559. 1872

Plant glabrate; leaves broadly ovate or suborbicular, rounded at the base, shortly acuminate at the apex, on long, stiff petioles; inflorescence almost as in $C$. paludosa typica; peduncle glabrous, but with a reddish tomentum at the base, 3-7-flowered; calyx subcampanulate, membranaceous, glabrous, caducous; lobes little smaller than in C. paludosa typica, and subdeltoid.

KaUAI: plateau of Waialeale, Wawra no. 2155 in Herb. Vienna (two sheets), det. by C. B. Clarke; part of type in herb. College of Hawaii.

Cyrtandra Paludosa Gaud. var. Gayana (Heller) Rock. Cyrtandra Gayana Heller, Minn. Bot. Stud. 9: 887, pl. 59. $\quad$ I897.

A small tree, $3 \mathrm{~m}$. high, the trunk usually Io $\mathrm{cm}$. in diameter; leaves opposite, lanceolate, tapering at both ends, 5-7.5 cm. long, about $2 \mathrm{~cm}$. wide, entire, bright green above, with impressed midrib and veins, covered with a brown pubescence underneath, the petioles 
I.5 cm.; flowers solitary or two, in the axils of the leaves, on a peduncle of $3 \mathrm{~mm}$.; pedicels 6-I $5 \mathrm{~mm}$.; calyx thin, slightly pubescent, as in C. paludosa typica; fruit ovate-oblong, $10 \mathrm{~mm}$., tipped with the persistent style.

KAUAI: on the ridge west of the Hanapepe river, elevation 3,000 feet, and on the plateau above Waimea 4,0oo ft. elevation, Heller, no. 2495; forests of Kaholuamano, above Waimea, flowering, March 3-10, 1909, Rock no. 2280 in herb. College of Hawaii; flowering and fruiting Sept. I909, Rock, no. 5600 in herb. College of Hawaii.

Heller says: "It belongs to the group of which C. paludosa is the type."

In fact it is merely a variety of $C$. paludosa, differing from it in its smaller, entire leaves and arborescent habit, otherwise the same. - Heller states that it may be identical with Wawra's Cyrtandra paludosa var. arborescens. This is however not the case. The writer was able to examine Wawra's plant, through the courtesy of Dr. Alexander Zahlbruckner of Vienna. Wawra's plant is now C. longifolia Hillebr. var. arborescens C. B. Clarke, and is identical with Hillebrand's $C$. paludosa var. integrifolia.

Cyrtandra Paludosa Gaud. var. haupuensis Rock n. var.

A small bush with thick angular branches; young shoots pubescent; leaves opposite, elliptical-olbong, subcoriaceous, dark green above, light brown underneath, glabrous on both sides, subentire, with a slightly undulate margin and faint crenation, $15^{-22} \mathrm{~cm}$. long, $3.5^{-5} \mathrm{~cm}$. wide, acute at the apex, gradually narrowing at the base into broadly auriculate margins; petiole $\mathrm{I} \mathrm{cm}$. long; inflorescence axillary; peduncle I-2 mm., 3-4-flowered; pedicels ro-I2 $\mathrm{mm}$.; calyx thin, glabrous, caducous, nearly as long as the tube of the corolla; fruits (immature) cylindrical-oblong, acuminate at the apex.

KAUAI: Lihue, near the summit of the Haupu range, flowering and fruiting March I8, I909, Rock, type no. 2473 in herb. College of Hawaii.

A very distinct variety, nearly worthy of specific rank; it differs from the species in its robust habit, subcoriaceous, subentire, auriculate leaves, and very short-peduncled inflorescence.

\section{SPECIMINA EXCLUDENDA}

C. paludosa Gaud. var. inerbacea Wawra no. 2070 in herb. C. B. Clarke $=$ Cyrtandra oenobarba Wawra var. herbacea Heller.

C. PAludosa Gaud. var. Confertiflora Wawra no. 2057 in herb. Vienna $=$ Cyrtandra confertiflora $\mathrm{C}$. B. Clarke. 


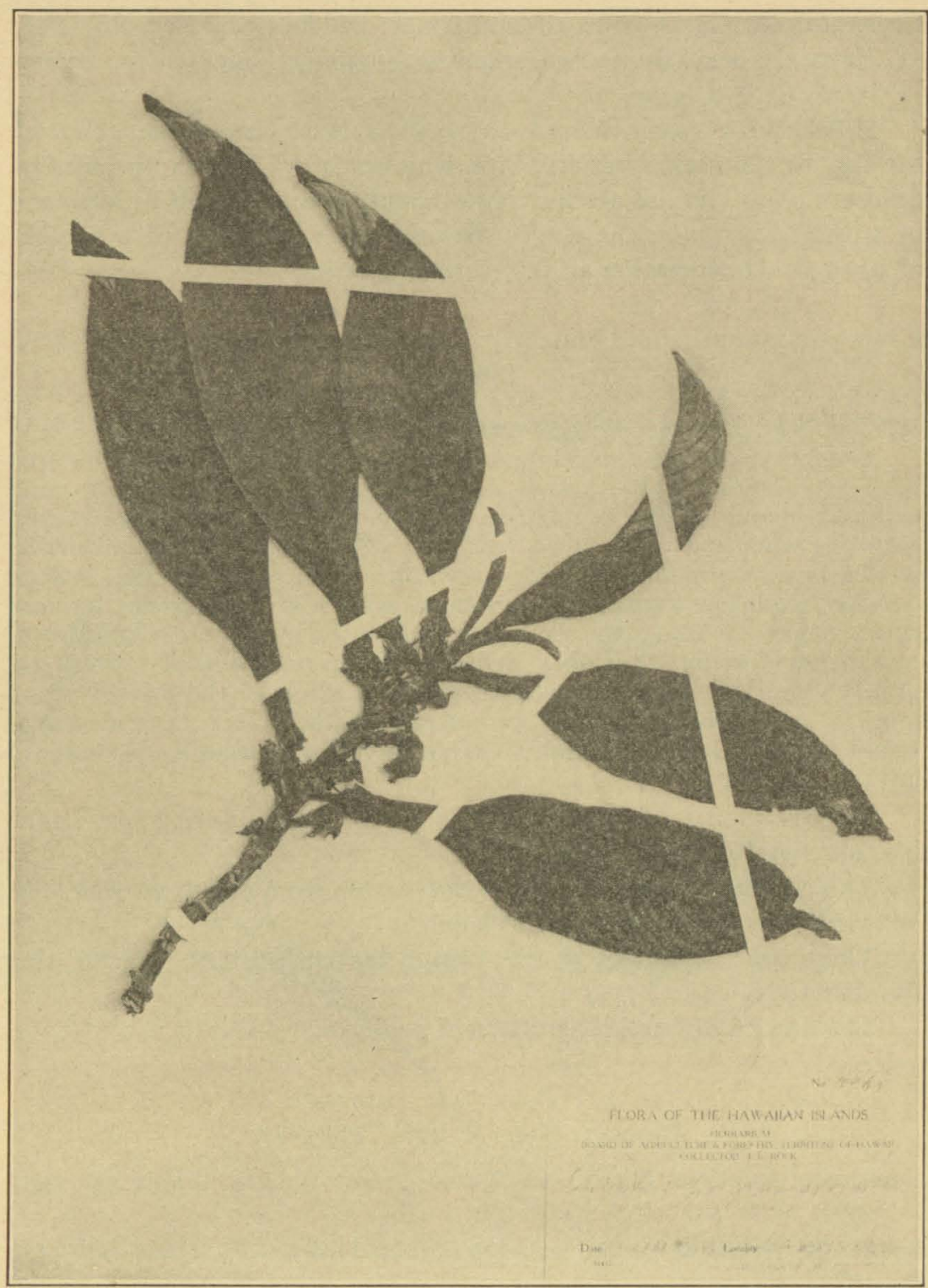

Fig. I. Cyrtandra paludosa Gaud. var. haupuensis Rock. Type in the College of Hawaii Herbarium. 
C. Paludosa Gaud. var. integrifolia Hillebr. Knudsen no. I37, Kauai, in herb. Berlin = Cyrtandra longifolia Hillebr. var. arborescens C. B. Clarke.

Hillebrand's specimen from the Kohala Mts. Hawaii and referred by him to the above variety with Knudsen's no. 137, is an entirely different plant and has absolutely nothing in common with $C$. paludosa or with $C$. longifolia; the leaves remind one very much of a species of Shorea. It represents an undescribed species.

Cyrtandra longifolia Hillebr.; C. B. Clarke, Monogr. Cyrt. 5: 276. I $883-87$

Cyrtandra paludosa Gaud. var. longifolia Wawra, Flora 55: 558. $\quad$ I872. Branches scarcely quadrangular, glabrate, the young parts hirsute with ferruginous hair; leaves opposite, shortly petiolate, o- I cm., elongate-oblong, acute, subentire, $22 \mathrm{~cm}$. long, $5 \mathrm{~cm}$. wide, nearly glabrous when mature," with a yellowish wool along the median nerve on the lower surface; peduncles $\mathrm{O}_{-}-5 \mathrm{~mm}$., of ten one-flowered; bracts narrow; pedicels $3 \mathrm{~cm}$. long, or longer, with a reddish-brown tomentum; calyx $12 \mathrm{~mm}$., the tube campanulate, with a reddish-brown tomentum outside, the lobes deltoid-acuminate; tube of corolla I4 mm., cylindrical, curved upwards, glabrous outside, the lobes $7 \mathrm{~mm}$. long, $4 \mathrm{~mm}$. wide, minutely pubescent inside; fruit $22 \mathrm{~mm}$. long, I cm. broad, broadly-oblong; calyx at first ampliate, persistent, later caducous.

KaUAI: Hanalei forests, collected by Wawra flowering and fruiting, no. I99I in herb. Vienna.

This species is only known to the writer from the type which is Wawra's No. I99I in the herb. Vienna.

There are two sheets in the Vienna herbarium both bearing the number I99I.

The flowers are on long pubescent pedicels.

Cyrtandra longifolia Hillebr. var. arborescens C. B. Clarke, Monogr. Cyrt. 5: 276 . $\quad 1883-87$

Cyrtandra paludosa Gaud. var. arborescens Wawra, Flora 55: 558. 1872.

Cyrtandra paludosa Gaud. var. integrifolia Hillebr. Fl. Haw. Isl. 337. I 888.

Branches thick, woody; leaves subentire, lanceolate, broader towards the apex; as in $C$. longifolia typica, but attenuate at the base 


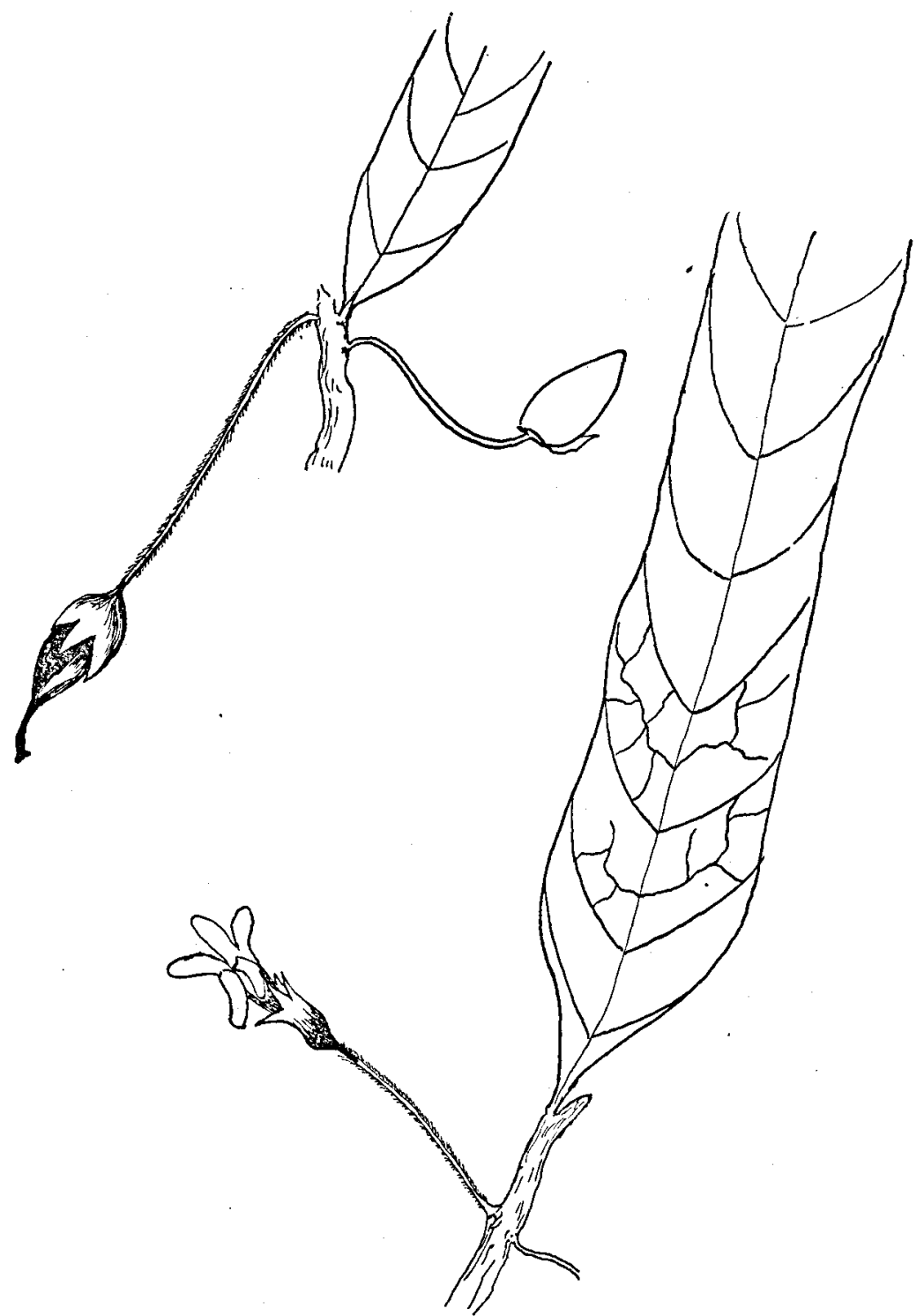

FIG. 2. Cyrtandra longifolia Hillebr. Sketched from the type in herb. Vienna, ex coll. Wawra, no. I99i. Hanalei, Kauai. 
and merging into a winged petiole of $2-7 \mathrm{~cm}$., or subsessile; peduncels nearly wanting, one-flowered, the rigid pedicels $\mathrm{I}-2 \mathrm{~cm}$., with reddish tomentum; calyx I6 mm. long, glabrous, caducous; fruit ovoidelliptical.

KAUAI: Wawra no. I99I $b$ (not $c$, as given by C. B. Clarke) in herb. Berlin, and portion of type in herb. College of Hawaii.

There are two sheets of this variety in the Vienna Herbarium; not represented in the Berlin Herbarium. This variety is only known to the writer from Wawra's collection.

Hillebrand's C. paludosa var. integrifolia from Kauai belongs here, rather than to the species on account of the much shorter pedicels.

Cyrtandra longifolia Hillebr. var. degenerans C. B. Clarke Monogr. Cyrt. 5: 277. I883-87

Cyrtandra paludosa Gaud. var. degenerans Wawra, 55: Flora 558. 1872. Cyrtandra paradoxa Hillebr. ms.

Cyrtandra latebrosa Hillebr. Fl. Haw. Isl. 337. I888.

Cyrtandra Hawaiiensis Drake del Cast. Ill. Fl. Ins. Mar. Pacif. 7:

253. I 892 , not C. B. Clarke.

Cyrtandra degenerans (Wawra) Heller, Minn. Bot. Stud. 9: 887. I897.

Stem straight, $2-4 \mathrm{~m}$. high, with a thick glutinous sap, the young shoots and inflorescence dark ferruginous, with a thick squamaceous tomentum; leaves verticillate, $3-5$ in a whorl, narrow-oblanceolate, I2-25 cm. long, $2-5.5 \mathrm{~cm}$. wide, acute to acuminate, entire or shortly dentate, chartaceous, dark green above, brownish underneath with a short and soft tomentum, prominently penninerved; peduncle very short, $2-4 \mathrm{~mm}$., I-5-flowered, the flowers drooping on pedicels scarcely longer than the peduncle; bracts linear-lanceolate, Io-14 $\mathrm{mm}$. long; calyx caducous, fleshy, shaggy outside and inside with dark squamaceous tomentum, $20-30 \mathrm{~mm}$. long, fusiform in the bud, with a lateral slit through which the corolla protrudes, the peaked top remaining entire or splitting into five short teeth; corolla slightly exserted, glabrate, curved, with large spreading limb, bilabiate, the upper "lip deeply emarginate, the lower three-lobed, 8-10 $\mathrm{mm}$. long; style twice as long as the glabrous ovary; berry olive-shaped, $26 \mathrm{~mm}$. long.

OAHU: Wawra no. 178I (two sheets) in herb. Vienna (type), and part of type in herb. College of Hawaii; in deep and dark ravines of Kalihi and Manoa, Hbd. without date or number, in herb. Berlin and herb. College of Hawaii (Kalihi spec.); Mts. of Punaluu, Koolau range along stream bed, flowering Aug. 1908, Rock, no. 9 in herb. College of Hawaii; Punaluu Mts., flowering Nov. I4-2I, I908, Rock 


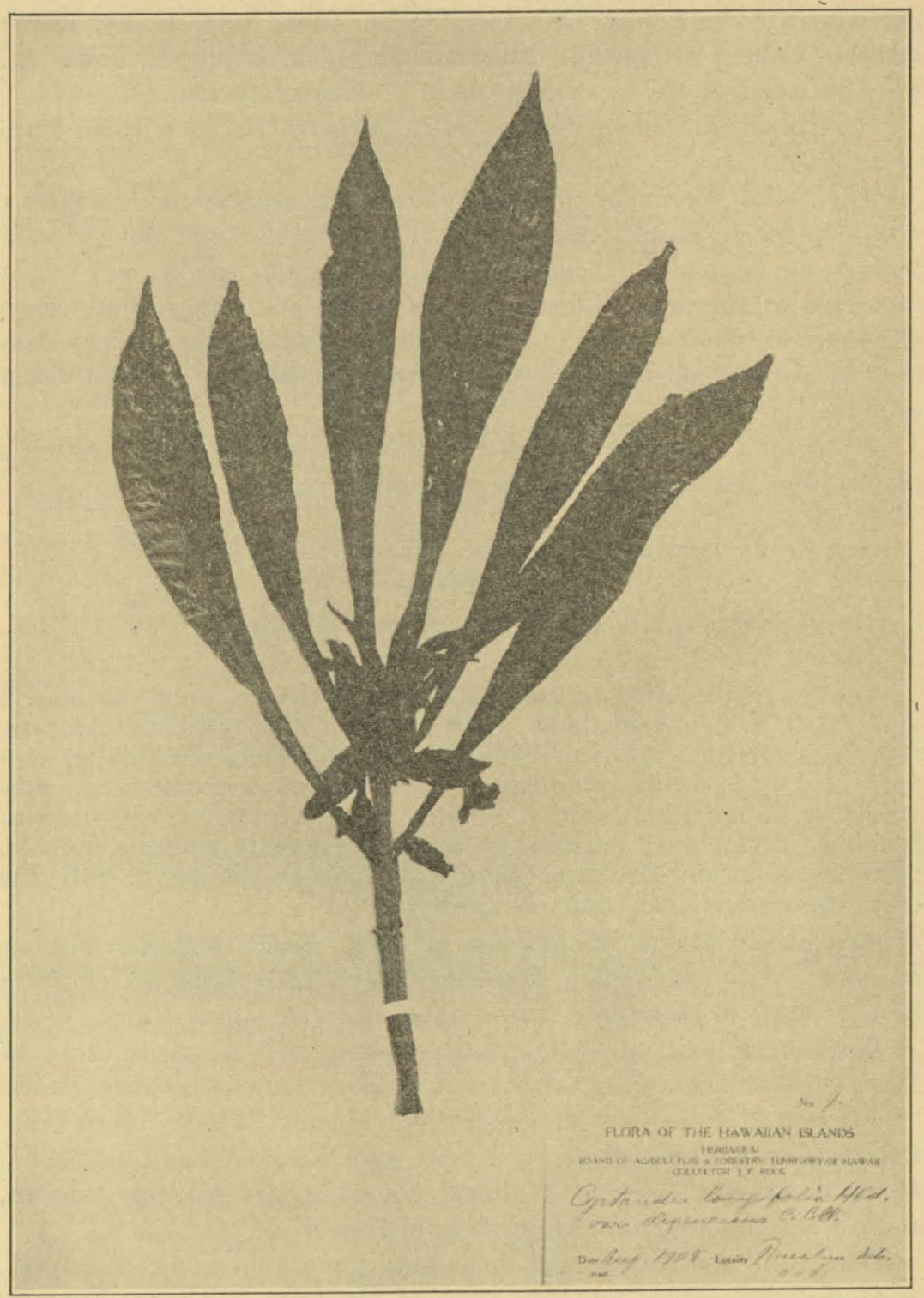

FIG. 3. Cyrtandra longifolia Hillebr. var. degenerans C. B. Clarke. Typical specimen. 
no. 933, 934; flowering Dec. 3-14, 24-29, 1908, Rock no. 157 \& 407 in herb. College of Hawaii; Kaukonahua gulch, Wahiawa, flowering, May 15, 1909, Rock, no. 3029 in herb. College of Hawaii.

Molokar: Mapulehu Valley, Hbd. in herb. Berlin without date or number.

The Oahu specimens are the typical var. degenerans; the plant occurs in the very wet forests usually in deep ravines and along stream beds in dense shade. It usually does not branch, but bears a crown of leaves at the end of a stem $3^{-4} \mathrm{~m}$. high, with the inflorescence clustered in the leaf-axils. It is a rather handsome plant and resembles somewhat certain species of the lobelioideous genus Cyanea in habit.

Hillebrand's specimens from Kalihi are identical with the writer's plants from the Punaluu Mts. of the same range.

Cyrtandra longifolia Hillebr. var. degenerans C. B. Clarke, forma subglabra Rock

Cyrtandra latebrosa Hillebr. var. $\beta$ subglabra Hillebr. Fl. Haw. Isl. 338. I 888 .

Leaves quaternate, almost glabrate underneath, only the midrib and veins reddish-tomentose, pale on both sides, shortly dentate, thin, chartaceous, obovate-oblong, acute to acuminate, $16-30 \mathrm{~cm}$. long, 4-6.5 $\mathrm{cm}$. wide, gradually contracting toward the base, subsessile or running out into a broadly winged petiole; calyx membranous, hirsute with dark brown hair, occasionally glabrate outside, but hirsute inside, fusiform; corolla as long as the calyx, only the lobes exserted, slightly hairy or glabrous.

MolokaI: Kalae, Hillebrand in herb. Berlin without date or number; Mapulehu Valley, flowering March I9Io, Rock no. I25I 8 in herb. College of Hawaii.

Maui: Honomanu Valley, along stream bed, northern slope of Mt. Haleakala, flowering, May I9I I, Rock no. I25I9.

HawaII: Valley of Holopalau in Kohala, Hbd.; Hamakua, Paauhau no. 3, forest, flowering July 5, I909, Rock nos. 406I, and 4062; Holokaiea gulch, back of Waimea, flowering and fruiting July Io, I909, Rock no. 408I in herb. College of Hawaii.

The Maui and Hawaii specimens have green, thin, glabrous calyces, and only the pedicel and nervature of the calyx is slightly hirsute, while the Molokai specimens have the whole calyx densely hirsute.

The leaves in the Maui and Hawaii specimens are also thinner and broader towards the apex, than those of Molokai. 
The specimen which Hillebrand records from Waiehu, Maui, belongs to the writer's forma cymosa.

Cyrtandra longifolia Hillebr. var. degenerans Wawra, forma cymosa Rock n. f.

Branches angular; leaves quaternate, broadly obovate-oblong, thin chartaceous, sparingly pubescent on both sides, dark green above, paler underneath, irregularly dentate, acute at the apex, $14-24 \mathrm{~cm}$. long, 4.5-9 cm. wide, contracting at the base into a broadly margined petiole, subsessile, or on petioles of $2-3 \mathrm{~cm}$.; inflorescence a cyme, hirsute with brownish hair throughout; bracts linear-lanceolate, acute, to subfoliaceous; peduncle $1.5-3 \mathrm{~cm}$., 3-8-flowered; pedicels I.5-2.5 cm.; calyx not fusiform, split into subdeltoid or linear-lanceolate, acute lobes, nearly glabrate or hirsute with brownish hair; corolla exserted; berry unknown.

MolokaI: Mapulehu Valley, flowering March I9Io, Rock no. I0334 in herb. College of Hawaii.

MaUi: Valley of Waiehu, Hillebrand, without date or number.

HAWAII: Holokaiea gulch back of Waimea, elevation 4,000 ft., flowering July Io. I909, Rock nos. 4075 and 4479 in herb. College of Hawaii.

The Hawaii specimens differ slightly from the Molokai specimens in the larger and denser flowered cyme and the linear-lanceolate, acute calycine lobes.

\section{Cyrtandra longifolia Hillebr. var. degenerans C. B. Clarke, forma oppositifolia Rock n. f.}

Branches quasi quadrangular; leaves opposite, obovate-oblong, acute at the apex, hirtellous on both surfaces, especially along the prominent midrib and nerves, with brownish hair, $15^{-22} \mathrm{~cm}$. long, 4-6 cm. wide, gradually contracting into a petiole of $2-3 \mathrm{~cm}$.; flowers single, or three on a common peduncle of $\mathrm{I}-\mathrm{I} .5 \mathrm{~cm}$.; bracts linearoblong, acute, $12 \mathrm{~mm}$.; pedicels 8 -Io $\mathrm{mm}$.; calyx not fusiform, split to near the base into 5, linear-oblong, acuminate lobes; peduncle, pedicels, and calyx hirsute with reddish-brown hair; corolla slightly exserted, lobes large, spreading, of unequal size, hirtellous or nearly glabrate; berry unknown.

MaUI: Western division, Honokawaii gulch, flowering Aug. I910, Rock no. 8206 in herb. College of Hawaii.

Differs from the other forms in the opposite leaves, deeply divided calyx, and large spreading corolla lobes. 


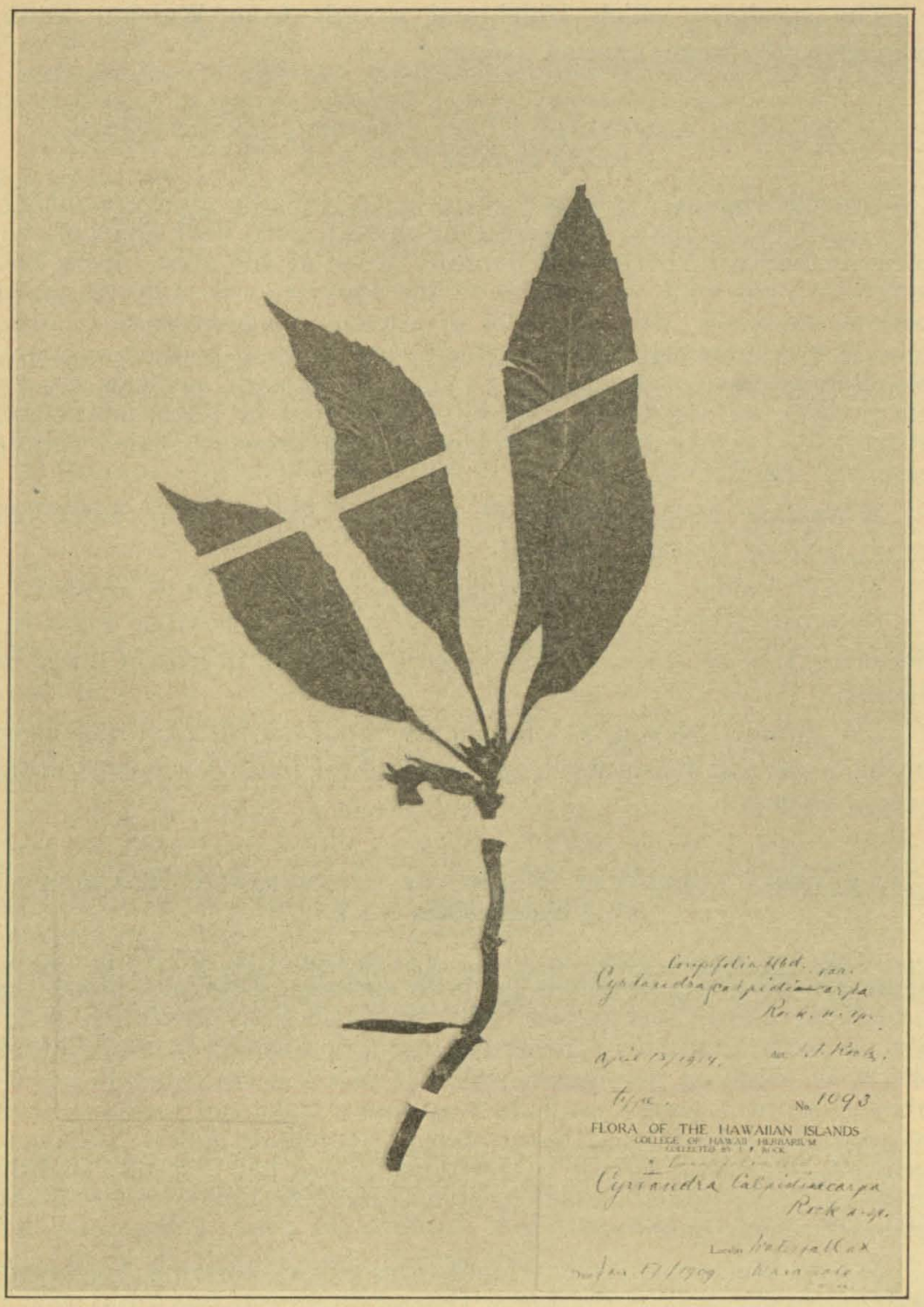

FIG. 4. Crytandra longifolia Hillebr. var. calpidicarpa Rock. Type in the College of Hawaii Herbarium. 
Cyrtandra longifolia Hillebr. var. degenerans C. B. Clarke, forma auriculaefolia Rock $\mathrm{n}$. f.

Stem fleshy; eaves quaternate, broadly obovate-oblong, obtuse at the apex, dark on both surfaces, as well as slightly pubescent, $18 \mathrm{~cm}$. long, $5.5^{-6.5} \mathrm{~cm}$. wide, subsessile, and broadly auriculate, with a basal diameter of about $3 \mathrm{~cm}$. in the older leaves; peduncle $3 \mathrm{~mm}$., usually three-flowered; pedicels $5 \mathrm{~mm}$.; calyx fusiform, thin, $20 \mathrm{~mm}$. long, subglabrous; corolla slightly exserted, the lobes small, unequal.

MaUr: Western division, Honokawai gulch, deep, shaded places, along the stream, flowering Aug. 25, I9ro, Rock no. 8159 in herb. College of Hawaii.

Differs from the other forms in the dark, broadly obovate-oblong, auriculate leaves.

Cyrtandra longifolia Hillebr. var. calpidicarpa Rock n. var.

Shrub I m. high, branching; leaves quaternate, elliptical-oblong, membranous, pale underneath, light green above, glabrous on both sides, excepting a reddish brown pubescence along the midrib, shortly and unevenly dentate, subentire in the lower portion, acuminate at the apex and base, IO-I $6 \mathrm{~cm}$. long, $3-4 \mathrm{~cm}$. wide, on a petiole of $2.5-3 \mathrm{~cm}$.; peduncle $2 \mathrm{~mm}$., 2-3-flowered, reddish-tomentose; pedicels $2 \mathrm{~mm}$; bracts foliaceous nearly as long as the calyx, the latter caducous, thin, fusiform, glabrate, excepting the acuminate lobes; corolla curved, exserted, $20 \mathrm{~mm}$. long, including the spreading, subequal lobes; berry long-cylindrical, $3 \cdot 5^{-4} \mathrm{~cm}$. long, $4 \mathrm{~mm}$. wide.

OAнu: Windward side, Waiahole Valley, on rocky wall, near waterfall at the head of the valley; flowering and fruiting Jan. I7, r909, Rock, type no. 1093 in herb. College of Hawaii.

Remarkable for its long cylindrical fruit which, in shape, reminds one of those of Calpidia. It is so far the only Cyrtandra found in these Islands, with a $4 \mathrm{~cm}$. long, cylindrical fruit.

\section{Cyrtandra Waianuensis Rock n. sp.}

Plant 1.5-2 m. high, erect, single stemmed, not branching; stem somewhat fleshy towards the apex, thick, woody and brittle towards the base, with a large crown of sessile leaves at the apex; leaves broadly oblong, subentire, or faintly dentate, dark green above, pale underneath, glabrous above, pubescent below, with fine yellowishbrown hair, obtuse or subacute at the apex, $30-45 \mathrm{~cm}$. or more long, I 5-20 cm. wide, thin, membranous to chartaceous, suddenly contracting at the base, sessile to subsessile; inflorescence densely clustered in the axils of the leaves on a common peduncle of $2-3 \mathrm{~mm}$., with 


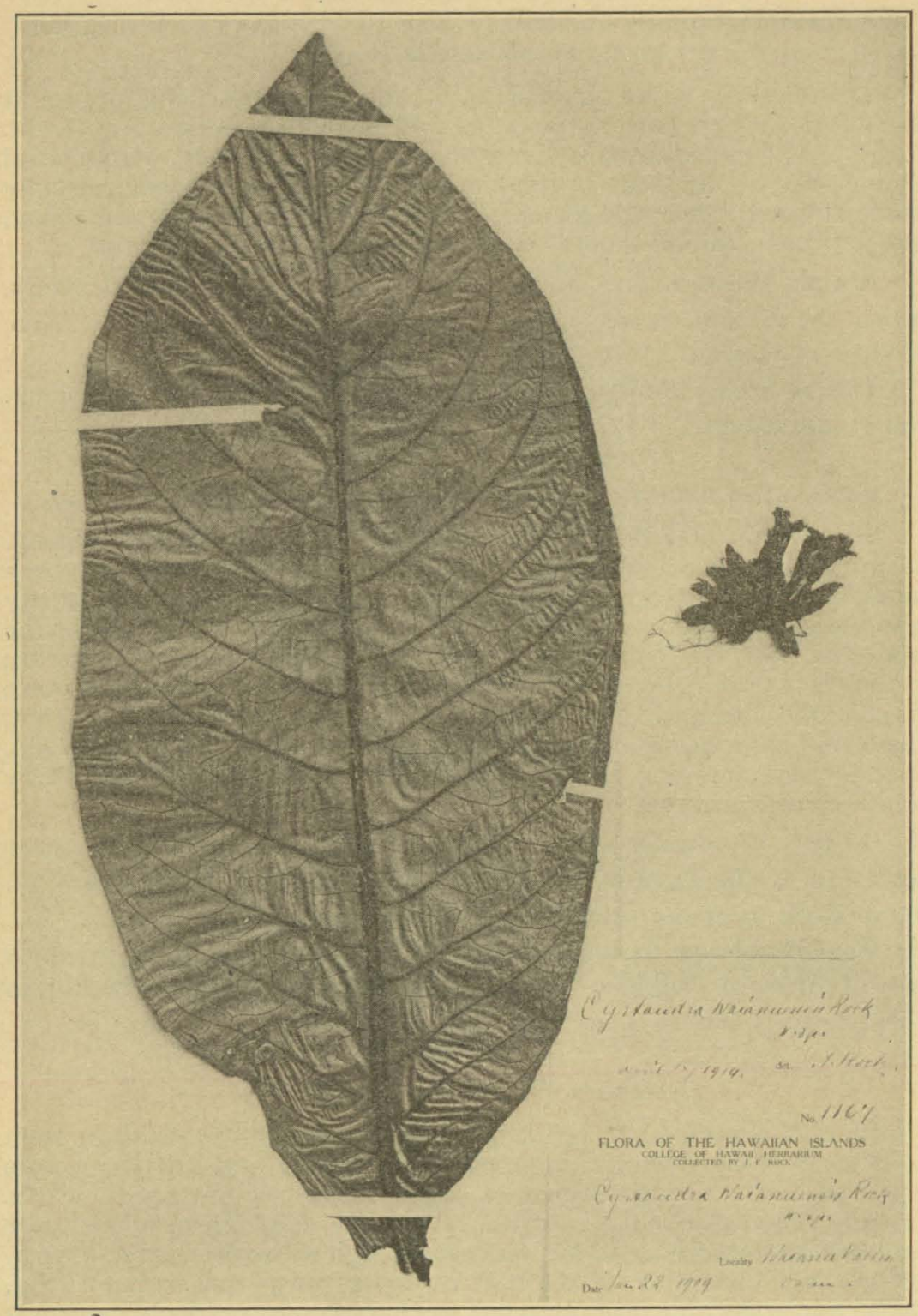

FIG. 5. Cyrtandra Waianuensis Rock. Type in the College of Hawaii Herbarium. 
numerous bracts at the apex, bracts oblong, acute, $12 \times 4 \mathrm{~mm}$.; pedicels I cm.; calyx caducous, thin, glabrous, green, fusiform, I5 $\mathrm{mm}$. long, the lobes acute, short; corolla slightly exserted, puberulous, the lobes very small and subequal; berry (immature) ovate-oblong, I $4 \times 5 \mathrm{~mm}$.

OAHU: Waianu Valley, windward side of the Koolau range, near the head of the valley, along stream-bed, flowering, Jan. 22, I909, Rock, type no. I I67 in herb. College of Hawaii.

A very interesting and striking species, remarkable for its large leaves, which are sessile. The species is single stemmed and at first glance resembles some of the Hawaiian Lobeliads, especially species of the genus Rollandia, in whose company the plant grows.

It is related to Cyrtandra longifolia var. degenerans and its forms.

\section{Cyrtandra cyaneoides Rock, Bull. Coll. Haw. 2: 39. I9I3}

Plant subherbaceous, somewhat woody at the base, the stem erect, not branching, II-I2 dm. high, $4 \mathrm{~cm}$. in diam., bearing a crown of leaves at the apex, not unlike a species of Cyanea; leaves 45-55 $\mathrm{cm}$. long, including the thick, winged petiole, $22.5-35 \mathrm{~cm}$. broad; midrib fleshy, obovate, rounded at the apex, suddenly narrowing below into a margined petiole, the latter $1.5 \mathrm{~cm}$. thick, texture of leaves thick, but coriaceous to fleshy, upper surface deeply rugose, the veins impressed, dark green, lighter underneath, glabrous, dull; young leaves and petioles covered with a light silky brown tomentum, with erose margins, the young leaves almost fringed; flowers numerous in subsessile clusters surrounding the stem, and hidden; calyx with prominent veins, curved, yellowish brown, five-cleft, bi-labiate, the lower lip consisting of two sepals, $12 \mathrm{~mm}$. long, suddenly narrowing into filiform apices, the upper lip of three sepals half as long as lower lip, the two outer ones only beaked, all parts covered with a silky brown tomentum; corolla enclosed in the calyx, white, $36 \mathrm{~mm}$. long including the $25 \mathrm{~mm}$. long tube, slightly curved, two upper petals rounded and smaller than the three lower which are acute, pubescent; stamens adhering in the lower half of the tube, the filament Io $\mathrm{mm}$. long; style I4 $\mathrm{mm}$. long, green, thickening towards the base; stigma flattened, two-lobed, the lobes obtuse, $2 \mathrm{~mm}$. long; fruit ovoid (immature), the calyx deciduous from fruit, on pedicels of 8-10 mm., and covered in its young state with a brown tomentum.

KAUAI: Forests of Kaholuamano, elevation 4,000 ft., on cliffs, near streams or waterfalls, along the trail of the Waialae Valley, flowering March 3, 1909, Rock, no. 2282 in herb. College of Hawaii.

One of the most striking species of Cyrtandra. It resembles a species of Cyanea of the section Palmaeformes, hence the specific name. The native name of this species is Mapele. 
Cyrtandra filipes Hillebr. Fl. Haw. Isl. 336. I 888

"Habit of C. grandiflora; leaves three or four in a whorl, flaccid, pale underneath and glabrate, oblanceolate, IO-I $5 \mathrm{~cm}$. long, 2.5-3.75 $\mathrm{cm}$. wide, on petioles of $8-\mathrm{I} 2 \mathrm{~mm}$., acuminate at both ends, remotely dentate or serrulate; flower solitary on a short peduncle of $\mathrm{I}-6 \mathrm{~mm}$., the slender pedicels many times longer, $18-36 \mathrm{~mm}$.; bracts filiform, 4-6 mm., soon caducous; calyx herbaceous, glabrous, cylindrical or campanulate, $\mathrm{I} 2-24 \mathrm{~mm}$., bilabiately five-fid to less than the middle, into sharply pointed, lanceolate lobes, deciduous from the fruit; corolla glabrous, as long as the calyx or longer, 20-28 mm., shaped as in C. grandiflora; ovary glabrous; berry slender fusiform I $8 \mathrm{~mm}$." 1

WEST MAUI: Gulches of Honokawai and Kaanapali, Hillebr., without date or number in herb. Berlin, part of type in herb. College of Hawaii.

The writer is only acquainted with this species from Hillebrandmaterial in the Berlin herbarium. It is related to the writer's $C$. longifolia var. calpidicarpa.

Cyrtandra grandiflora Gaud. Bot. Voy. Uranie $447 \cdot p l .55$. I 826

Cyrtandra Endlicheriana Walp. Nov. Act. Nat. Cur. 19, Suppl. I. 359. $t$. Io. $\mathrm{I} 843$.

Cyrtandra Ruckiana Meyen Reise 2, 125. I834.

A small shrub I-2 m. high; branches quadrangular, the new parts ferruginous-tomentose; leaves opposite, elliptical, acuminate at both ends, subentire, IO-I $4 \mathrm{~cm}$. long, 4-8 cm. broad, obscurely crenulate, thin, chartaceous, glabrate above, pilose underneath especially along the midrib and nerves; petioles $2 \mathrm{~cm}$.; cymes few-flowered; peduncle $2-6 \mathrm{~cm}$., I-7-flowered; bracts foliaceous, $2-3 \mathrm{~cm}$., ovate-lanceolate, subpetiolate or clasping at the base, greenish, deciduous; pedicels o-I cm.; calyx herbaceous, campanulate, I $8-24 \mathrm{~mm}$. long, unequally five-fid, the lobes broadly triangular, acute; corolla large, glabrous, exserted, 30-32 mm., the tube curved, the limb bilabiate, large, spreading; ovary glabrous, style articulate at the base; fruit $16 \mathrm{~mm}$. long, $8 \mathrm{~mm}$. broad, ellipsoidal, glabrous, white, the calyx deciduous.

\section{Insulis Sandwicensibus, Gaudichaud.}

OAHU: Beechey in herb. Kew; Meyen, flowering specimen in herb. Berlin, two sheets, one labeled Cyrtandra Rucriana, only leafspecimen, det. by C. B. Clarke as C. grandiflora; Mann et Brigham no. 40 in herb. Kew; Nuttall in herb. British Museum; Nuuanu

${ }^{1}$ Hillebrand's description is here quoted, only the measurements have been changed from inches to the metric system. 
Valley, flowering I868, Hillebrand, without number, in herb. Berlin; Wawra no. I746 (flowering), in herb. Vienna (four sheets); Pauoa Valley, flowering, Nov. 4, I908, Rock no. 704; same locality, flowering Oct. 29, I909, Rock no. I0346.

In the Berlin herbarium with the Hillebrand material, is a sheet labeled $C$. grandiflora, collected in the Malay peninsula, State of Pahang in 1909 , no. 13673 ; this plant does not belong to our C. grandiflora Gaud.

The calyx and flowers of that specimen are silky tomentose, and in other respects it does not agree with our plant. The Meyen specimen is labeled C. Rucriana, while C. B. Clarke cites it in his monograph as C. Ruckiana.

A very distinct species common in the valleys back of Honolulu, a branching shrub with large white attractive flowers; occurs only at lower elevations of 500-r,000 feet, usually in dense shade along water courses.

Cyrtandra oenobarba Mann, Proc. Amer. Acad. 7: i89. I866

Low, decumbent, 3-6 dm. high, fleshy, the stem and petioles shaggy with stiff, dark-brown, reflected hairs; leaves ovate or subcordate, acute at the apex, denticulate, hirsute with reddish hairs along the veins underneath, glabrate above, fleshy, $6.25-8.75 \mathrm{~cm}$. long, about $6 \mathrm{~cm}$. wide, on stout petioles of $2.5-5 \mathrm{~cm}$.; peduncle oneto two-flowered, as long as the petioles; calyx shaggy, oblong, 5-fid, the lobes ovate lanceolate, sharply acuminate, foliaceous; corolla slightly exserted, fully $2.5 \mathrm{~cm}$. long, glabrous, the limb large, spreading.

KAUAI: Wahiawa falls and Waioli, foot of Waialeale, Mann and Brigham no. $6 \mathrm{I} 6$.

It seems that this species has only been collected by Mann, for the writer found no material of it in any of the collections, neither in those of Wawra nor Hillebrand. C. B. Clarke in his monograph says also "species non visa."

The writer is not acquainted with the species but with the variety petiolaris Wawra.

Cyrtandra oenobarba Mann var. Petiolaris Wawra, Flora 55: 563. I 872

Cyrtandra oenobarba Mann var. rotundifolia Wawra, 1. c.

Cyrtandra oenobarba Mann var. obovata Hillebr. Fl. Haw. Isl. 338. I 888 . 
Plant low, procumbent, $12-36 \mathrm{~cm}$. high; leaves opposite, elliptical, acute or rounded at both ends, ro- $14 \mathrm{~cm}$. long, $6 \mathrm{~cm}$. wide, remotely serrate, glabrate above, with blackish-brown tomentum along the midrib and veins, otherwise pale and glabrate; petioles $5-7 \mathrm{~cm}$., with blackish hair; peduncle very short $5 \mathrm{~mm}$., densely villous with blackish hair; bracts $8 \mathrm{~mm}$., oblong, deciduous; pedicels 2-4, o-8 $\mathrm{mm}$. long; calyx $2 \mathrm{~cm}$. long, narrow, tubular, divided to the middle into 5 , linear-lanceolate lobes, covered with blackish to yellowish hair; corolla $3 \mathrm{~cm}$., glabrate; fruit $16 \mathrm{~mm}$. long, $3 \mathrm{~mm}$. broad, narrow cylindrical, the calyx persistent.

KaUAI: Wawra no. 2012,2157 in herb. Vienna, and portion of type of no. 2012 in herb. College of Hawaii; Hanapepe fall, Abbe Faurie, flowering Dec. I909, no. 625 (distributed as C. oenobarba Mann), in the herb. College of Hawaii, as no. 12520.

A distinct variety, differing from the species in the long petioles, - very short peduncle, and pedicels; it is identical with Wawra's var. rotundifolia which seems to differ from it only in the glabrous leaves.

Cyrtandra oenobarba Wawra var. herbacea (Wawra) Heller, Minn. Bot. Stud. 9: 890. I 897

Cyrtandra paludosa Gaud. var. herbacea Wawra, Flora 55:559. 1872.

Herbaceous, procumbent; branches fleshy, villous with reddish to grayish hair; leaves fleshy, elliptical or subovate, I7 cm. long, 6-Io $\mathrm{cm}$. wide, coarsely serrate, on petioles of $2-6 \mathrm{~cm}$.; peduncles very short, o-9 mm., many-flowered; pedicels short, of ten o-7 mm.; calyx glabrous; corolla large, curved, glabrous; fruit unknown.

KaUAI: Hanapepe falls, Wawra no. 2070 in herb. Vienna; same locality, July, Heller no. 2490 in part, distributed as C. oenobarba.

Wawra's specimen no. 2070 is a distinct variety but comes close to $C$. oenobarba var. petiolaris. It has nothing in common with C. paludosa.

College of Hawait, Honolulu 